\title{
SIMULANT COMPOSITION FOR THE MIXED WASTE MANAGEMENT FACILITY (MWMF) GROUNDWATER REMEDIATION PROJECT (U)
}

by J. L. Siler

Westinghouse Savannah River Company

Savannah River Site

Aiken, South Carolina 29808

WSRC-RP-92-224

DE93 001354

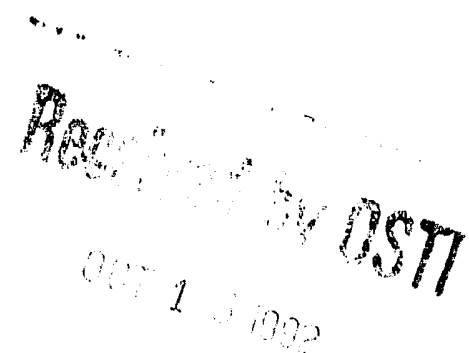

This paper was prepared in connection with work done under Contract No. DE-AC09-89SR18035 with the U. S. Department of Energy. By acceptance of this paper, the publisher and/or recipient acknowledges the U.S. Government's right to retain a nonexclusive, royalty-free license in and to any copyright covering this paper, along with the right to reproduce and to authorize others to reproduce all or pari of the ccpyrighted paper. 


\section{DISCLAIMER}

This report was prepared as an account of work sponsored by an agency of the United States Government. Neither the United States Government nor any agency thereof, nor any of their employees, makes any warranty, express or implied, or assumes any legal liability or responsibility for the accuracy, completeness, or usefulness of any information, apparatus, product, or process disclosed, or represents that its use would not infringe privately owned rights. Reference herein to any specific commercial product, process, or service by trade name, trademark, manufacturer, or otherwise does not necessarily constitute or imply its endorsement, recommendation, or favoring by the United States Government or any agency thereof. The views and opinions of authors expressed herein do not necessarily state or reflect those of the United States Government or any agency thereof.

This report has been reproduced directly from the best available copy.

Available to DOE and DOE contractors from the Office of Scientific and Technical Information, P.O. Box 62, Oak Ridge, TN 37831; prices available from (615) 576-8401, FTS 626-8401.

Available to the public from the National Technical Information Service, U.S. Department of Commerce, 5285 Port Royal Rd., Springfield, VA 22161. 


\section{Westinghouse Savannah River Company WSRC-RP-92-224 \\ Savannah River Laboratory}

Keywords: MWMF Groundwater

Remediation Project,

Trichloroethylene,

Simulant Composition,

Groundwater Remediation

Retention Time: Permanent

January 31, 1992

To: D. L. Fish, 773-A

From: J. L. Siler, 676-T\&\&్S

Simulant composition for the Mixed Waste Management Facility (MWME) Groundwater Remediation Project (U)

\section{SUMMARY}

A project has been initiated at the request of $E R$ to study and remediate the groundwater contamination at the Mixed Waste Management Facility (MWMF). This water contoins a wide variety of both inorganics (e.g., sodium) and organics (e.g., benzene, trichloroethylene). Most compounds are present in the ppb range, and certain components (e.g., trichloroethylene, silver) are present at concentrations that exceed the primary drinking water standards (PDWS). These compounds must be reduced to acceptable levels as per RCRAVorders. and CERCLA

This report gives a listing of the important constituents which are to be included in a simulant to model the MWMF aquifer. This simulant will be used to evaluate the feasibility of various state of the art separation/destruction processes for remediating the aquifer.

\section{INTRODUCTION}

Elevated concentrations of various inorganic and organic constituents have been observed in the groundwater at the MWMF. Fo: example, the trichloroethylene (TCE) concentration has been measured and the average level is $164 \mathrm{ppb}$. The primary drinking water standard (PDWS) for TCE is 5 ppb. Forty years of operations have resulted in substantial amounts of solvents and metals entering the soil and reaching shallow aquifers. The simulant described in this document is designed to closely model the aquifer under consideration. This will provide a study of the feasibility of several standard wastewater treatment schemes to remediate this aquifer. 


\section{SIMULANT COMPOSITION}

The simulant used in these experimental studies has been developed based on analyses from actual groundwater wells at the MWME [reference: Dames \& Moore (1991)]. Several RCRA-regulated species are present in this waste stream, but the concentrations are low enough to permit normal laboratory practices to occur. Standard carcinogen-handling practices have to be observed when using the pure organic liquids to prepare the simulant. The species to be tested, along with typical concentrations, are listed below (numbers in parentheses are for the ion of interest):

Species

$\mathrm{AgNO}_{3}$

$\mathrm{Al}_{2}\left(\mathrm{SO}_{4}\right)_{3}$

$\mathrm{Ca}(\mathrm{OH}) 2$

$\mathrm{Cd}\left(\mathrm{NO}_{3}\right)_{2} \cdot 4 \mathrm{H}_{2} \mathrm{O}$

$\mathrm{FeCl}_{3} \cdot 6 \mathrm{H}_{2} \mathrm{O}$

$\mathrm{Ee}\left(\mathrm{NO}_{3}\right) 3 \cdot 9 \mathrm{H}_{2} \mathrm{O}$

$\mathrm{Fe}_{2}\left(\mathrm{SO}_{4}\right)_{3}$

$\mathrm{KOH}$

$\mathrm{Mg}(\mathrm{OH}) 2$

$\mathrm{NaOH}$

$\mathrm{Na}_{2} \mathrm{~S} \cdot 9 \mathrm{H}_{2} \mathrm{O}$

$\mathrm{Na}_{2} \mathrm{SO}_{4}$

$\mathrm{Pb}\left(\mathrm{NO}_{3}\right) 2$

$\mathrm{Zn}\left(\mathrm{NO}_{3}\right)_{2} \cdot 6 \mathrm{H}_{2} \mathrm{O}$

Benzene

Carbon tetrachloride

1,2 DCE

Trichloroethylene (TCE)

Tetrachloroethylene (PCE) concentration, pob

104 (66 as Ag)

$12,700(2,000$ as Al)

$1.067 \mathrm{E} 6 \quad(576,000$ as $\mathrm{Ca})$

$10,500 \quad(3,817$ as Cd)

$55,700(11,508$ as $\mathrm{Fe})$

$19,900(2,751$ as $\mathrm{Fe})$

$9,560(1,335$ as $\mathrm{Fe})$

206,500 (144,000 as K)

$7,470 \quad(3,107$ as $\mathrm{Mg})$

$1.5 \mathrm{E} 6(862,130$ as $\mathrm{Na})$

$11,500(2,202$ as $\mathrm{Na})$

$65,800(21,300$ as $\mathrm{Na})$

$112(69.8$ as $\mathrm{Pb})$

$395(87.1$ as $\mathrm{Zn})$

46

41

23

164

30

These species were chosen for specific individual reasons. All of the listed organics, along with $\mathrm{Cd}, \mathrm{Pb}$, and $\mathrm{Ag}$ are present in excess of their PDWS. The remainder of the cations (other than $k$ and $\mathrm{Na}$ ) were chosen because of low solubilities, which could result in deposition/fouling and possible upset of the proposed process.

These compolinds will be blended in various combinations and tested in the following laboratory-scale unit operations:

1. filtration

2. reverse osmosis

No testing is planned for a chemical oxidation system to evaluate destruction of the organics because a large number of vendor studies and case histories are available. 
D. I. FISH

\section{QUALITY ASSURANCE}

The work described in this report will be performed according to the guidelines in the SRS QA manual. This simulant recipe and various other tests feeds, along with the data collected during these tests, will be recorded in laboratory notebook \#WSRC-NB-90256 .

\section{REFERENCES}

Dames \& Moore, "Westirighouse Savannah River Site Mixed Waste Management Facility Review of Remedial Technologies", Job \#10805-537-0C9, March 7, 1991.

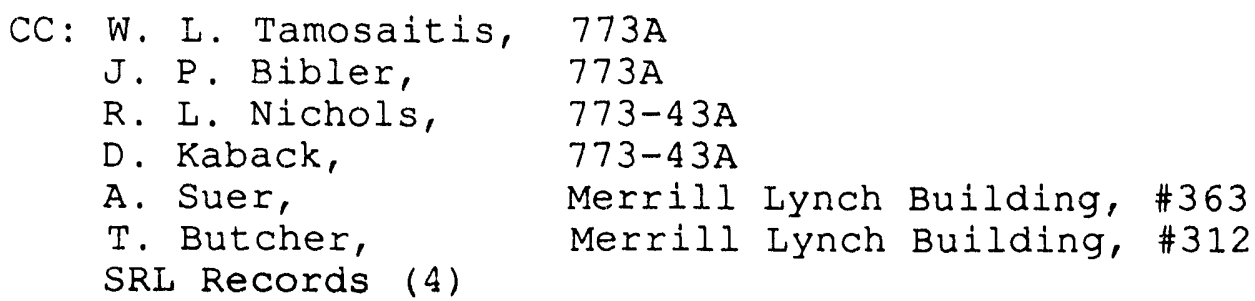



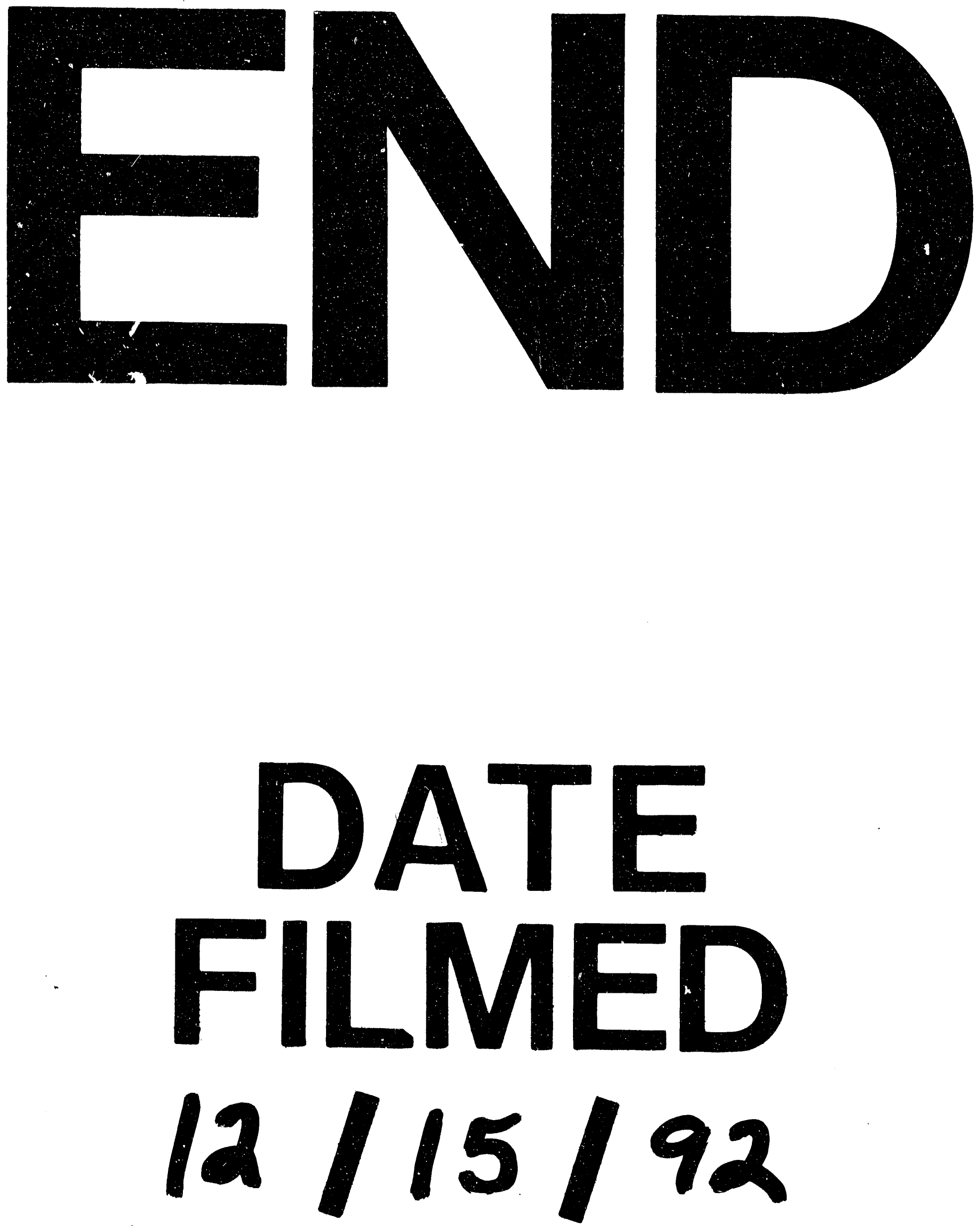
